\title{
Odin og Hvide Krist: Om Sune Aukens bog Sagas spejl. Mytologi, historie og kristendom hos N. F.S. Grundtvig, København, 2005
}

\author{
Af Thorkild C. Lyby
}

Efter et kort referat af Sune Aukens ovennævnte bog og forløbet af disputatsen på Københavns Universitet uddybes i det følgende den opposition ex auditorio, som forfatteren af nærværende artikel der fremførte. Idet afhandlingens påvisning af et manglende "ligeløb" mellem Grundtvigs teoretiske og poetiske anvendelse af mytologien i perioden 1815-32 anerkendes som et gyldigt og værdifuldt resultat, tages to problemkompekser op til nærmere overvejelse, nemlig 1) hvad forstår Grundtvig ved gudbilledlighed? og 2) har Auken ret i, at asalæren for Grundtvig får karakter af religion? Det hævdes, at der højst kan blive tale om religiøsitet, men ikke om en egentlig religion.

Den 3. juni 2005 forsvarede cand. mag. Sune Auken på Københavns Universitet den ovennævnte afhandling for den filosofiske doktorgrad. Ikke uden grund havde han som motto sat følgende Grundtvig-citat: "smaa Bøger er de vanskeligste at skrive". Bogens tekst fylder 631 sider, hvortil kommer 104 sider med engelsk resumé, noter, litteraturliste og register. Alene bogens størrelse viser således, at der er tale om en usædvanlig præstation.

Som det fremgår af undertitlen, er der tale om et tværfagligt arbejde, og det må straks konstateres, at Auken er i stand til at yde alle de tre nævnte fag retfærdighed. Det er jo ikke nogen hemmelighed, at litterater og teologer har forskellige tilgange til studiet af Grundtvig, og man tør vel også sige, at der har hersket en vis konkurrence mellem dem, således at man ikke altid har kunnet blive enige om, hvem der repræsenterer den rigtige tilgang. På den baggrund er det en fornøjelse at kunne konstatere, at litteraten Aukens bog er præget af en usædvanlig forståelse for den teologiske tilgang, og at dens fremstilling af forholdet mellem litterær og teologisk Grundtvig-forskning yder begge parter retfærdighed. Hans opgørelse af mellemværendet (56-58) er så kvalificeret og så loyal, at man tør sige, at kun en litterat, der desuden halvvejs var teolog, ville kunne gøre det så overbevisende - og dermed også dokumentere nødvendigheden af gensidig respekt og samarbejde.

At Auken selv er litterat, og at han som sådan først og fremmest er tekstanalytiker, er på den anden side umiskendeligt. Det fremgår til overmål af den måde, han behandler sit stof på. Under henvisning til Grundtvigs egen stil og udviklingen af hans tænkning afviser han 
blankt til indledning at give en dækkende definition af netop de tre begreber, der står i centrum af undersøgelsen. I stedet hævder han frimodigt, at afhandlingen i sig selv må gøre det ud for definitionen. Specielt for ordet "mytologi" gør han ganske åbenlyst krav på en ret til at bruge det på tvetydig måde, og for ordet "profet" er der endog tale om flertydighed, således at han kan skrive "at det jævnligt betyder det ene, jævnligt det andet og nu og da begge dele" (12) - vel at mærke ikke blot hos Grundtvig, men i hans egen afhandling! Alt dette må naturligvis virke frustrerende på en teolog, der er en hund efter definitioner. På den anden side kan man ikke lukke øjnene for, at enhver definition er en afgrænsning, således at der med opstillingen af en definition også altid vil være noget, man afskærer sig fra at forholde sig til - især hvis man har med en forfatter som Grundtvig at gøre, hvis arbejder er præget af en stadig strøm af nye idéer, indskud og sidebemærkninger. Ikke uden grund taler afhandlingen om hans ufattelige mangfoldighed og associationsrigdom (99). Dette må i sig selv problematisere en skarpt definerende tilgang, og det må derfor indrømmes, at kravet om stringente definitioner ikke er den allerbedste forudsætning for en tilgang til Grundtvig.

Indledningsvis skitserer Auken den nybesindelse på mytologiens væsen, der udvikledes i Tyskland i slutningen af det 18. århundrede. I erkendelse af, at kristendommens tid som sammenhængende verdensanskuelse var forbi, søgte man at fremtolke eller skabe en ny mytologi, "der kunne danne et sammenhængende og urørligt eller helligt eksistentielt, religiøst og erkendelsesmæssigt grundlag under menneskets forestillingsverden" (17). Det påvises, at Grundtvig var under indflydelse af denne bevægelse, og at dette er en vigtig forudsætning for forståelse af "asarusen". Gennem skarpsindige og åndfulde analyser af en række af Grundtvigs værker, specielt Nordens Mytologi (1808), Et Blad af Jyllands Rimkrønike (1815), Nyaars-Morgen (1824), Nordens Mythologi (1832) og Christenhedens Syvstjerne (1859) når Auken frem til det overraskende resultat, at mytologien for den unge Grundtvig bliver til noget i retning af en alternativ religion. Da han alligevel ikke kan slippe den kristendom, han er opvokset i, nødes han til at søge at kombinere den med asalæren. At dette totalt mislykkes er en af de vigtigste forudsætninger for hans sammenbrud i december 1810. Fra 1815 opgiver han derfor helt at beskæftige sig teoretisk med myterne, idet de dog stadig spiller en afgørende rolle i hans poesi, således at der opstår et "manglende ligeløb" mellem hans forsøg på teoridannelse og hans poetiske praksis. Kun ganske langsomt og egentlig først med Nordens Mythologi (1832), hvor myterne opfattes som sindbilleder, bringes hans tænkning over forholdet 
mellem mytologi, historie og kristendom på niveau med anvendelsen af mytologien i det lyriske forfatterskab. Først her bliver det klart for ham, hvilken rolle mytologien kan og bør spille i hans tilværelsesforståelse. Og selv da dette er klaret for ham, kan hans tænkning over forholdet kun i ganske generelle træk dække hans brug af mytologien i digtekunsten og aldrig bringes til at udtømme eller fuldt ud begribe den poetiske praksis (88).

Klarlæggelsen af dette forhold udgør efter min mening bogens vigtigste resultat, som fuldt ud kvalificerer sin ophavsmand til doktorgraden. I tilgift får vi så den implicitte hævdelse af, at poesien rummer en form for erkendelse eller indsigt, som ikke uden videre lader sig gøre op i stringente begreber - utvivlsomt en vigtig forudsætning for forståelsen af Grundtvig, der jo til stadighed "søger at udtrykke det, der ikke lader sig udtrykke" (625).

Auken høstede megen og fortjent ros ved forsvaret. Første officielle opponent og medlem af bedømmelsesudvalget, professor S. A. J. Bradley, York, nævnte hans fremragende evner for fortolkning af digtene og fandt, at det er analyserne, der hæver arbejdet til videnskab af højeste rang. Dog savnede han en konsolidering af den teoretiske basis og påpegede den nærliggende fare for subjektivisme. Vel vil analyserne af så speciel en forfatter som Grundtvig uundgåeligt være præget af hans stil, men når han lader uforståelighed blive forklaret ved uforståelighed, stilles der så meget større krav til stringensen i analysen. I øvrigt fandt han, at der kunne have været mere opmærksomhed omkring forholdet til det liturgiske år, ligesom han mente, at Grundtvigs forhold til den angelsaksiske digtning var blevet stedmoderligt behandlet.

Cand. mag. Svend Skriver mente, at Auken ikke fuldt ud havde udnyttet mulighederne i den værkanalytiske metode. Han kunne have ofret mere opmærksomhed på den formelle struktur i samspillet forfatter - tekst - læser. Grundtvig arbejder jo også rent teknisk på at komme i dialog med læseren. Hvor meget eller hvor lidt betyder formen for forståelsen af hans værker?

Docent, dr. phil, Flemming Lundgreen-Nielsen fandt, at det bedste ved bogen var analyserne fra og med Et Blad af Jyllands Rimkrønike. Fortolkningen af Nyaars-Morgen er så god, at en dobbeltspaltet udgave med digtet på den ene side og Aukens analyser på den anden ville kunne gøre det ud for den kommenterede udgave, vi så længe har savnet. I øvrigt gjorde Lundgreen-Nielsen opmærksom på, at mytologien egentlig aldrig var kommet til at spille den rolle i dansk 
kulturliv, som Grundtvig havde forestillet sig - muligvis på grund af det vanskelige sprog, han formidlede den $i$.

Anden officielle opponent var formanden for bedømmelsesudvalget, lektor, dr. phil. Johnny Kondrup, der betegnede Auken som en fremragende læser af digteriske tekster, men fandt, at hans krav om præcision over for andre ikke i samme grad blev gjort gældende over for ham selv. Han var fintmærkende, lydhør og skarp over for andres tekster, men uopmærksom over for egne. Hans ordrige fremstilling var præget af en parataktisk, mundtlig stil, og der var modsigelser og uklarheder, som burde have været opløst. Både metodekapitlet og behandlingen af andre forfattere var kritisable, og hvad angik tesen om det manglende ligeløb 1815-32 spurgte Kondrup, om denne uoverensstemmelse egentlig var andet end en funktion af forskellen mellem poesi og prosa. I hvert fald var terminologien usikker.

Efter opfordring skal jeg gengive nogle af de synspunkter, jeg som tredje opponent ex auditorio og som medlem af bedømmelsesudvalget gjorde gældende.

Et enkelt sted er Auken kommet til at røre ved et punkt, hvor jeg som teolog er lidt hudløs. Det drejer sig om s. 160, hvor han analyserer skriftet Indbydelse til Gamle Nordens Venner. I forbindelse med overvejelser over forholdet mellem forskellige tidsaldre og mellem tiden og evigheden taler Grundtvig her også om menneskets gudbilledlighed. Vi bevæger os her i schellingske tankebaner, og det er jo nok forklaringen på den ret betænkelige gradbøjning af gudbilledligheden, Grundtvig her er ude i. Men så fortsætter Auken uheldigvis selv med en kort karakteristik af, hvad Grundtvig senere forestiller sig, når han taler om gudbilledlighed. Han skriver:

Senere i forfatterskabet bliver forestillingen den, at der trods menneskets fald og afmagt er noget godt i mennesket, som Gud kan genløse, men her kan geniet helt selv, og i ham hviler menneskeslægtens håb.

Formodentlig skal udtrykket "noget godt i mennesket" forstås som en vis, begrænset og ufuldstændig evne til at gøre det gode - eller med Regin Prenters ord: "en religiøs-moralsk potens" (Prenter 1983, 64)? Der findes respektable teologer - for ikke at tale om respektable ikketeologer - der vil tilslutte sig denne opfattelse. Men på mig virker den ikke desto mindre som en rød klud. Hvis den senere Grundtvig skulle mene, at der dog er "noget godt" i mennesket, som Gud kan genløse, hvad så med resten? Er det ikke netop noget centralt hos Grundtvig, at mennesket som helhed er Guds gode skabning, at det som helhed er faldet og at det som helhed skal genløses? Og hvordan med forholdet 
til Luther? For ham betød syndefaldet jo, at både menneskets vilje og evner er så fordærvet, at det er helt ude af stand til at bidrage til sin egen frelse. Det kan kun frelses ved en suveræn, guddommelig indgriben. Hvis frelsen blot i mindste måde er afhængig af det faldne menneskes egen indsats, så er den utroværdig. Hvis Grundtvig skulle mene, at der dog er noget godt i mennesket, som Guds nåde kan arbejde sammen med, så forstås syndefaldet jo væsentligt mindre radikalt end hos Luther. Så er vi ovre i den teologi, der ser en samvirken eller en synergisme mellem Guds nåde og menneskets gode gerninger som vejen til frelse - den opfattelse, som man plejer at kalde semipelagiansk, og som særlig har fundet anerkendelse inden for den romersk-katolske kirke. Men selv mente Grundtvig dog vist, at han netop fortsatte Luther - blot under andre forhold, således at deres fronter nok kunne vende forskellige veje, men at de dog i princippet var ens. ${ }^{1}$

På denne baggrund behøver vi næppe gå nærmere ind på den straks efterfølgende sætning, at "her kan geniet helt selv". Det må være nok at sige, at der fra et teologisk synspunkt her er tale om ren og skær pelagianisme. Og den sætning står da heller ikke hos Grundtvig.

Efter min mening findes der en ganske anden måde at forstå Grundtvig på. Det gælder specielt den senere Grundtvig. Når han taler om, at mennesket ikke er uoprejseligt faldet, eller, som det hedder andre steder, at gudbilledligheden er bevaret, så tror jeg slet ikke, at han opfatter gudbilledligheden som en etisk kvalifikation. Jeg tror, for nu at udtrykke det lidt håndfast, at gudbilledligheden for ham består $\mathrm{i}$, at mennesket kan tale og høre. Hvad det jo stadig kan!

Også tanken om menneskets gudbilledlighed har været omstridt, og jeg vil indrømme, at min opfattelse kan være lidt forenklet; men forkert er den ikke. I GSV IV 276-77 finder vi digtet "Hvor skal jeg Guds Billed finde?" (1850/51), som simpelt hen er én stor udfoldelse af tanken om ordet som Guds billede. Ganske vist begyndes der med at fastslå, at Jesus er det egentlige, genfødte Guds billede. Men i lyset af ham ses det, at gudsbilledet hos os kun er halvt forsvundet, og at det til sin tid skal fornyes helt. Og forbindelsen mellem os, Kristus og Gud er ordet, som det fremgår af strofe 3:

Jesus Kristus, Guddoms-Manden

Er Guds Billed og Guds Ord,

Han har talt, som ingen anden,

Som Guds Mund af Støv paa Jord,

Kan vi høre og forstaae

Hvad Guds-Ordet lyder paa,

Har til det vi Mund og Mæle,

Er Guds Speil i vore Sjæle! 
Og i strofe 4:

Ordet om hvad intet Øie

Gjort af Kiød og Blod kan see,

Ordet om den evig Høie,

Paa hvis Ord Alting maa skee,

Dette Ord med Aand og Liv

Gienlyd af Guds Almagts-Bliv

Det Guds Billed er herneden,

Og Hans Glands i Evigheden

Men gælder denne "guddommeliggørelse" af ordet da også vores ord? Svaret kommer i strofe 5:

Kunde vi det Ord ei høre,

Da for os vor Gud var stum,

Kunde vi det Ord ei føre,

Dødt var Evangelium,

Var Guds Billed ei deri,

Blinde var for Gud da vi,

I Livs-Ordet, som ei feiler,

Lysets Gud hos os sig speiler!

Det gudbilledlige hos mennesket er ordet. Det er fællespunktet mellem Gud og menneske, kontaktpunktet mellem det jordiske og det himmelske. Derfor er det igennem ordet, at Gud åbenbarer sig for mennesket, ganske som det er igennem ordet, at mennesker åbenbarer sig for hinanden. I Haandbog i Verdenshistorien (Grundtvig 1869, III, 466-467, jf. US VII, 703) udfolder han tanken i prosa, idet han taler om "de to store Vildfarelser", som desværre er taget for kristelige grundsandheder, nemlig, "at Menneskelivet ved Syndefaldet havde tabt al Lighed med Gudslivet, og at al christelig Oplysning havde sin Kilde i Bibelen." Først i Danmark

fandt man det soleklart, at dersom der nu slet ingen Lighed var mellem Gud og Menneske, saa kunde Mennesket hverken lære at kiende Gud eller sig selv, og at den Oplysning, der skulde udspringe af en Bog, maatte være dødere end en Sild.

Derfor erklærer han det for indlysende,

at baade maae vi, for at kunne skifte Ord med Gud, have Ordet tilfælles med Ham, og derhos maatte Gud tiltale os paa vort

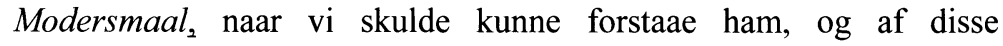
Forudsætninger følger det med Nødvendighed, at der er en Lignelse af alt Guddommeligt hos os ...

Derfor hedder det i 1866 i digtet Nornerne: 
Kun i Ordet Jorderige

Fundet har en Himmelstige

(PS IX, 211).

Her er der ikke tale om en etisk kvalifikation, men om antropologi. I en tidligere strofe hedder det:

Mellem Jord og Himmel svinger

Ordet sig af Munden ud,

Livet, som deraf udspringer,

Har kun Mennesket af Gud.

(PS IX 209).

Her er der tale om en ægte grundtvigsk brander. Rent fysisk er munden placeret mellem jorden og himmelen. Men samtidig er det ord, der udgår af den, $\mathrm{i}$ antropologisk forstand udtryk for menneskets mellemstilling mellem jorden og himlen. Som naturvæsen er mennesket bundet til jorden. Men ordet, der er åndens redskab, viser, at det desuden er et åndsvæsen - placeret mellem jord og himmel, mellem natur og ånd. Det er ved ordet, mennesket adskiller sig fra både dyr og planter. Og deri ligger gudbilledligheden:

Mennesket er i Guds Billede skabt

Med Ordet i Kraft paa sin Tunge,

Og derfor kan han mellem Træer og Dyr

Med Guderne tale og sjunge.

Menneske-Børn i den grønne Lund

Hvor Fugle i Bøgene sjunge!

I skjønne derpaa: det er Guderne ligt

At tale med Menneske-Tunge.

(VU VIII, 432).

Jeg skal herefter komme ind på det, der for mig er et af de mest kontroversielle resultater i afhandlingen, nemlig påvisningen af, at den nordiske mytologi i Grundtvigs ungdom har betydet så meget, at der ligefrem kan tales om en konflikt mellem den og kristendommen, og at dette er en væsentlig årsag til sammenbruddet i 1810, til den mangeårige lammelse af det teoretiske arbejde med myterne og til det manglende "ligeløb" mellem det teoretiske og det poetiske arbejde.

De skarpeste formuleringer af dette synspunkt får man i det indledende afsnit "Afhandlingens synspunkt", hvor det s. 46 hævdes, at " $\mathrm{i}$ den unge Grundtvigs udlægning er mytologien faktisk et selvforløsende religiøst system, der overflødiggør kristendommen som frelsende kraft" - og senere, at 
Asalæren bliver i al sin abstraktion til en forløsningsreligion, til en fuldstændig historiefilosofi, der forklarer tilværelsen i lyset af en overordnet historisk fortolkningsramme, fører frem til saligheden og dermed befrier mennesket (46).

Det stemmer hermed, at det s. 202 hævdes, at Grundtvig i 1811 på det teoretiske plan stort set har lagt mytologien bag sig, hvorefter der fortsættes: "Dette er det eneste punkt i Grundtvigs liv, hvor der er tale om en egentlig omvendelse". Og s. 179 hævdes det om samme situation, at Grundtvig her for første og eneste gang optræder "som ægte konvertit”.

Her er der jo virkelig smæk for skillingen. Om Auken senere er blevet betænkelig ved disse stærke ord, skal jeg lade være usagt; men det er i hvert fald, som om han under det videre arbejde har modereret sig lidt. Tonen er dæmpet lidt ned, når det s. 155 siges, at "de nordiske myter [har] en quasi-religiøs betydning" - ligesom der s. 291 står, at værkerne Om Asalceren og Nordens Mytologi (1808) "til en vis grad [har] karakter af religion. De udtrykker en metafysik af mindst quasireligiøs karakter, der er selve løsningen på verdensgåden." Her savner man virkelig klarhed og definitioner. Her bør vi spørge hinanden og os selv, hvad vi egentlig mener med ordene "religion" og "religiøs" (se herom senere, s. $155 \mathrm{ff}$.).

Først vil vi dog se på de udtalelser af Grundtvig, der må komme i betragtning ved spørgsmålet om, hvorvidt asalæren for ham var blevet til religion.Vi har vel alle kendt til begrebet asarusen og været mere eller mindre tilbøjelige til at betragte den som en kort, lidt sværmerisk begejstringsperiode, der ret hurtigt er gået over. At vi har kunnet tænke på den måde, kan måske skyldes, som Auken med rette gør opmærksom på, at emnet er ret uopdyrket. Det kan måske også skyldes, at det har været svært at fatte, at den mand, som man har kaldt Danmarks "kirkefader", virkelig skulle have dyrket asatroen i en sådan grad, at den kunne problematisere hans forhold til kristendommen. Men et problem er der, hvad hans digte fra 1808 tydeligt viser. Hvad skal man for eksempel stille op med det berømte vers fra Maskeradeballet i Dannemark:

Høje Odin! Hvide Krist!

Slettet ud er eders Tvist.

Begge Sønner af Alfader

(US I, 233)?

Hvad skal man stille op med drapaet til Willemoes, hvor der står:

Med inderlig Tillid til Asernes Magt

Jeg bad, at jeg Hærfaders Sal maatte skue, 
Og aaben stod Valhal i herlige Pragt

(US I, 753)?

Hvordan skal man forstå svaret til Molbech, hvor han skriver:

Kan nogen skue høje Strid,

Som føres mellem Lys og Mørke,

og Lyset fra den svundne Tid;

Og Nordens Aser ikke dyrke?

(PS I, str. 3, 44).

Og værst af alt: Hvad skal man stille op med digtet om Gunderslevholms skov, hvor han nærmer sig en stendysse, som han fejlagtigt antager for at være et alter for aserne, og hvor digtet kulminerer i linjerne:

O, er det ej Alterets mossede Stene,

Som Egenes Grene

Saa tætte omhvælver?

Det er! - O, jeg skjælver

Jeg dirrer af Lyst,

Og hellige Andagt opfylder mit Bryst,

Jeg iler, jeg iler med vingede Fjed,

For Asernes Alter at kaste mig ned

Og prise de hensovne Guder. (PS I, 40-41).

Det er skrap kost, og det har været svært at komme til rette med det. Hal Koch skriver, at "Disse Linier skal naturligvis ikke forstaas bogstaveligt som en Tilbedelse af Nordens Guder" $(1944,52)$. Det samme mener Edvard Lehmann $(1929,61)$, C. I. Scharling (1947, 87-88) og William Michelsen $(1956,34)$, der alle anfører Grundtvigs egne, senere udtalelser til støtte for deres opfattelse. Og gennem en indtrængende analyse når Flemming Lundgreen-Nielsen (1980) frem til, at digtet er

et symbolsk digt om stræben mod og erobring af et åndeligt mål, ikke en skildring af en ung fusentasts ubetænksomme henrykkelse (...) Den besværlige vandring frem til stenene afbilder hans besværlige forsken i oldskrifterne (I, 248).

Personligt kender jeg kun to arbejder, der nærmer sig Aukens opfattelse. Det ene er Rønnings snart 100 år gamle værk, hvori han ganske vist afviser, at Grundtvig bogstavelig talt skulle have knælet, men hvor han dog (II, 90) skriver, at "den bevægelse, som Asernes alter vækker i hans sjæl, den er ikke blot videnskabelig interesserethed eller digterisk begejstring; den er, paa sin vis, religiøs aerefrygt og tilbedelse". Og s. 85 citerer han i en note Sibbern for at have sagt, at "man sagde den gang om 'Grundtvig, at hans tro var Asatroen"'. Det 
andet er Niels Kofoed $(1954,88)$, der om det efterfølgende digt til Molbech skriver, at det "levner ingen tvivl om, at den ekstatiske begejstring kun kunde finde afløb i en kultus". - Michelsen (s. 34, nt. 7) tilbageviser med henvisning til et brev fra Povl Dons denne udtalelse og konkluderer: "Grundtvig tilbad ikke selv guderne, men han begejstredes ved tanken om at stå på det sted, hvor forfædrene havde gjort det”. Jeg kan nu ikke få så klart et resultat ud af Dons' brev som Michelsen, og jeg mener som Auken, at Michelsen her har gjort den unge Grundtvig for kristeligt from (68 med note 103 (64950)).

Det er rigtigt, at Grundtvig senere skarpt dementerede, at der skulle have ligget noget religiøst $i$ hans forhold til aserne. Det sker blandt andet i artiklen "Om Afguderie" (1813). Han er her temmelig ophidset, idet han både fra svensk og fra tysk side er blevet kritiseret for, at han har forladt den guddommelig sande religion, nemlig asalæren, og er faldet fra til nyere tiders tomme afgudsbilleder, det vil sige til kristendommen. I sit svar indrømmer han, at han har været en hedning, men kun i sin rationalistiske periode. Han henviser til sit forfatterskab fra 1806 til 1810 som klart bevis på sin kristendom og hævder, at han selv i sine mest sværmeriske arbejder (!), nemlig Om Asalceren og Nordens Mytologi, har erklæret kristendommen for åbenbaret sandhed og kun har lovprist asalæren som det sandeste, mennesker har digtet, og det sandeste, man kunne have uden for Palæstina, før Kristus kom til jorden. Han erklærer med eftertryk, at han aldrig har troet på indbildningskraftens tomme afgudsbilleder og aldrig i panteistisk raseri har bøjet sig for Odin og Thor, skønt der hist og her, "som i Maskeradeballet (1808), i det om Asalæren, i Indledningen til Nordens Mythologi, i Verset om Gunderslev Skov og flere Steder, ere Udtryk, som jeg hader og afskyer" (US II, 697). Han genkalder og fraskriver sig på det højtideligste ethvert ord, som ikke kan bestå for sandhedens, det vil sige for Bibelens domstol; han forsikrer, at han fremtidigt ikke vil sige det mindste i vers og billede, som han ikke holder for vis, kristelig sandhed, og han bekender sin kulsviertro på den hellige skrift efter dens bogstavelige, det er ordrette mening.

To år senere optrykker han $\mathrm{i}$ samlingen Kvaedlinger digtet "Gunderslev Skov", idet han i den vedføjede kommentar kalder de famøse linjer for "Daarekistesnak" og "Løgn", idet han erklærer, at han lige så lidt udvortes som indvortes nogen sinde har bøjet knæ for slige afguder (PS I, 41). Og om verset fra Maskeradeballet siger han:

Hver Christen seer let, at det er formastelige Ord, som, naar de toges strængt, maatte betyde, at Christus var som Odin kun en Idee, et 
luftigt, indbildt Væsen. Det var nu ikke min Mening; jeg følde selv, det var usømmelig talt, og sendte derfor aldrig min salig Fader den Bog ... Ordene lader jeg kun staa til min Skam (VU I, 147 nt.).

Det er altså med meget skarpe udtryk, han fralægger sig et religiøst forhold til asatroen. De er så skarpe, at man kan blive lidt mistænksom. Specielt Om Afguderie virker så lidenskabelig, at man kunne få den tanke, at han er ramt på et meget ømt punkt, og at han egentlig kæmper lige så meget for at redde sin egen samvittighed som for at overbevise andre. Man må desuden betænke, at disse stærke ord er skrevet efter krisen 1810-11, hvor han var nået frem til et klart kristent, ja endog biblicistisk standpunkt. På dette tidspunkt var konflikten løst og valget truffet, og det kan meget vel have stillet hans tidligere holdninger $\mathrm{i}$ et ganske andet lys, end de dengang stod for ham. Ikke uden grund siger han selv i Mands Minde, at vi må "aldrig af nogen, endsige af de mere poetiske Naturer, forlange en upartisk Skildring af deres Ungdom" ( VU IV 307).

Og der er jo også efter asarusen udtalelser, der peger $\mathrm{i}$ en anden retning. På baggrund af fralæggelserne må man undre sig, når man $\mathrm{i}$ hyldestdigtet til hans moder, som også er trykt i Kvoedlinger, læser linjerne:

Foer jeg vild i Ungdoms Dage,

Vild fra Gud og fra Hans Ord,

Foer jeg vild med Asa-Brage,

Fandt jeg seent min Frelsers Spor,

Skjøndt der for min Vugge sjunget

Var saamangen Psalme sød

Hvad! Om da jeg var udsprunget

Af en vantro Moders Skjød! (US III, 65).

Altså: Hvis ikke han havde haft sin moders kristentro som baggrund, kunne det være gået helt galt. - Man må også undres, når man i brevet til W. Østrup af 29. juni 1811 læser: "Du veed det, at jeg alt i nogle Aar har gældt for en Kristen, og syntes mig selv at være en saadan; men kun daarlig stod det sig med min Kristendom". Han betegner ganske vist sine fejl som hovmod og urenhed. Men fortsættelsen inddrager dog netop mytologien:

Jeg kaldte mig Kristen og talte haarde Ord til den ukristne Flok; men tvertimod al kristen Kærlighed øvede jeg mig i Spotvers og istedenfor at arbeide i Herrens Vingaard og gaa min gamle Fader tilhaande, ophøjede jeg i Kvad og Skrift de gamle Hedninge og deres Afguder.

Mærkelig er også skildringen af krisen i 1810: "Underlig greb mig Herren i sidst forgangne Høst, jeg følte mig udrevet af Hedendommet 
og stemt til at leve ene for Kristi Tjeneste" ( $V U$ I, 285-86). Og straks efter går brevet over i en beretning om sammenbruddet $i 1810$.

Grundtvigs mange bekendelser af, at han hele tiden har været kristen, kan næppe anfægte Aukens opfattelse af, hvad mytologien har betydet for ham. Hans tesis er jo netop, at sammenbruddet er fremkaldt af den konflikt mellem asatro og kristendom, der efterhånden var blevet uudholdelig. Det kan den jo kun blive, hvis begge dele betyder noget helt afgørende for ham. De stærke udtryk for, at han hele tiden har været en kristen, rokker derfor ikke ved tesen.

Problemet med Aukens fremstilling er imidlertid, hvad man egentlig forstår ved religion. Ser man efter i diverse opslagsværker, fremgår det med al tydelighed, at der ikke findes nogen alment anerkendt definition på ordet. For så vidt kan man opstille hver sin. Et forsøg på at vurdere, om Aukens opfattelse kan holde, må derfor selv antage en tentativ form. Alligevel vil jeg som modstykke til Aukens lidt flagrende tanker gå til den modsatte yderlighed og søge at opstille ret stramme kriterier for, hvad man kan kalde religion. Og ifølge det tilløb til definition, som jeg har kunnet stykke sammen fra forskellige kilder, må en fuldt udviklet religion have to sider, nemlig dels en indre, individuel side, der rummer både et intellektuelt og et emotionelt element, det vil sige både tanke og følelse - og en ydre, kollektiv side, der giver sig udtryk i samfundsdannelse og kult. Hertil kommer lære og etik, som efter min mening kan spille en rolle både inden for religionens indre og dens ydre side. Bevæbnet med dette begrebsapparat kan vi så vende os til Grundtvig og spørge, i hvilket omfang Auken har ret $\mathrm{i}$ at bestemme hans betagelse af asalæren som religion.

Man må straks kunne blive enige om, at den ydre side af en eventuel asareligion mangler. Man kan diskutere, om Grundtvig rent fysisk faldt på knæ i Gunderslevholms skov, i hvilket sidste tilfælde der måske kunne tales om kultus, som Kofoed gør. Jeg tror det nu ikke; og i givet fald måtte man dog vel tale om en ret ufuldstændig form for kultus. Heller ikke kan man tale om samfundsdannelse. Begge dele kommer under ét til at fremstå som en komisk umulighed, hvis man prøver at forestille sig Grundtvig som arrangør af en egentlig, ritualiseret asakult med blotfest i Dyrehaven eller lignende. Hvad angår lære og etik, må jeg som nævnt tage forbehold over for en alt for skarp opdeling mellem den indre og den ydre side af religionen. Vi kan ikke tale om lære eller etik uden dermed også at tale om religionens indre, individuelle side. Som lære vil den omfatte både et intellektuelt element, nemlig en overbevisning om, at der findes en højere magt, og en tilværelsesforståelse i tilknytning til denne 
overbevisning - og et emotionelt element, nemlig en følelse af tilknytning til og afhængighed af denne magt. Om begge disse elementer kan man bruge ordet tro. På disse punkter kan man vel ikke helt udelukke, at Grundtvigs betagelse af mytologien tenderer mod en religiøs holdning. Alligevel må man vel sige, at der næppe er tale om egentlig tro. De gamle guder var "hensovne". Han troede ikke på dem som levende og handlende væsener. Han overtog derimod den tilværelsesforståelse, som forestillingerne om dem var udsprunget af, og mente, at myterne udtrykte sandheder om menneskelivet, som var nødvendige for et sundt menneskeliv i Norden. Derved kommer det etiske perspektiv ind i billedet. Meningen med at udsende disse bøger var jo, at både hans egen og hele hans samtids livsførelse skulle præges af det livssyn, han fandt i myterne.

Mens vi således nok kan se bort fra det, vi har kaldt religionens ydre side, så kan man, hvad angår den indre side, tro, tilværelsesforståelse og etik, ikke uden videre afvise, at der er tale om noget, man kunne kalde en religiøs holdning. Men det er ikke det samme som en religion. Ifølge Vilhelm Grønbech er religion en religiøsitet, der har taget form. Man må dog vist sige, at der i Grundtvigs tilfælde snarere er tale om religiøsitet end om religion. Religiøsiteten ligger ikke i så faste former, at ordet religion kan bruges. Konklusionen må blive: Jeg tager forbehold over for Aukens mere bastante formuleringer, men akcepterer udtrykket "quasi-religiøs", som ganske vist er uskønt, og som jeg gerne så erstattet med et mere velklingende dansk, men som dog forekommer mig at ramme mere præcist, end nogen tidligere karakteristik har gjort.

På trods af uklarhederne er jeg altså enig med Auken i, at man bør tage asarusen mere alvorligt, end man sædvanligvis har gjort. Og gør man det, kan opfattelsen af adskillige forhold i denne og den følgende periode måske endda nuanceres lidt. Dermed skal naturligvis ikke være sagt, at tidligere forklaringsforsøg pludselig skulle være blevet værdiløse. Men der er måske spørgsmål, som kommer til at stå i et lidt andet perspektiv på denne baggrund. For eksempel: Hvorfor sendte han ikke Maskeradeballet i Dannemark hjem til sin gamle fader? Var det, fordi de kritiske spørgsmål, han frygtede, netop kunne komme til at dreje sig om hans forhold til kristendommen? Hvorfor slog han sig så voldsomt i tøjret, da forældrene bad ham komme hjem og blive kapellan for faderen ( $V U$ I, 261-67)? Der var andre og gode grunde til det. Men det kunne måske også skyldes, at han ikke kunne forlige tanken om at blive kristen præst med den halvreligiøse betagelse af myternes tilværelsesforklaring. Det kunne måske netop være presset hjemmefra om at blive præst, der satte konflikten på spidsen. Det er i 
hvert fald umiddelbart efter brevvekslingen om dette, sammenbruddet kommer. I Kirke-Speil ser han selv krisen udløst af de to spørgsmål, der pludselig står for ham: "Er du selv en Kristen? og har du dine Synders Forladelse?" (US X, 342). Som gode lutherske teologer har vi vel altid lagt vægten på den sidste sætning. Men man kunne måske også tage den første sætning alvorligt. Som nævnt fandt han det i det tidligere citerede brev til W. Østrup problematisk, om han overhovedet var kristen i tiden forud for sammenbruddet. Og man kunne tænke på den skovoplevelse den 31. maj 1811, som Chr. Thodberg har gjort opmærksom på. Endnu i "Farvel til min Ven Sibbern" vinder "Sagas Runer" sig som en solkrans om Kristi pande (PS I, 323, jfr. 330). Men digtets to højdepunkter er ordinationen, hvor han følte sig forsonet med Gud, og skovoplevelsen, hvor han fattede mod til præstegerningen (sst. 326-28, jfr. 333-34). Måske var det først her, konflikten virkelig blev løst?

Som før bemærket: Der findes ikke nogen alment anerkendt definition på begrebet religion. For så vidt kan man til enhver tid hævde, at stoffet passer til éns egen. Og Auken har jo virkelig et bud, idet han forklarer udtrykket "forløsningsreligion" som en historiefilosofi, der forklarer tilværelsen og fører frem til saligheden (jf. 150 her). Jeg kan ikke tilslutte mig identifikationen af historiefilosofi og forløsningsreligion. Og jeg kan slet ikke se, at en historiefilosofi skulle kunne overflødiggøre kristendommen som frelsende kraft eller føre frem til saligheden. Det kan Grundtvig næppe heller have ment. Med andre ord: Jeg kan ikke bruge Aukens definition på "religion".

Ikke desto mindre må jeg bevidne min respekt for Aukens arbejde. Det er et kæmpeværk, han har leveret, og det er med rette allerede blevet udråbt til et hovedværk og en milepæl i Grundtvig-forskningen. I kraft af bogens dybt borende analyser er vi trods alt blevet væsentligt klogere på den unge Grundtvig, end vi før var, og der er åbnet perspektiver, der må virke både oplysende, inspirerende og berigende på os andre. Der er al god grund til at ønske ham hjerteligt til lykke med dette.

\section{Forkortelser}

GSV: Th. Balslev et al. (udg.) (1944-64), Grundtvigs Sang-Voerk, bind 1-6, København.

PS I-IX: Svend Grundtvig (udg.) (1880-1930), N. F. S. Grundtvigs Poetiske Skrifter, bind 1-9, København.

US I-X: Holger Begtrup (udg.) (1904-09), Nik. Fred. Sev. Grundtvigs Udvalgte Skrifter, bind 1-10, København. 
$V U$ I-X: Georg Christensen og Hal Koch (udg.) (1940-49), N. F. S. Grundtvigs Varker $i$ Udvalg, bind 1-10, København.

\section{Litteraturliste}

\section{Værker af Grundtvig}

Balslev, Th. et al. (udg.) (1944-64), Grundtvigs Sang-Vark, bind 1-6, København.

Begtrup, Holger (udg.) (1904-09), Nik. Fred. Sev. Grundtvigs Udvalgte Skrifter, bind 1-10, København.

Christensen, Georg og Hal Koch (udg.) (1940-49), N. F. S. Grundtvigs Voerker i Udvalg, bind 1-10, København.

Grundtvig, N. F. S. (1808), Maskeradeballet $i$ Dannemark, København. Optrykt i US I, 224-240, hvorfra der her citeres.

— (1808), "Svar til min Ven Molbech" i PS I, 43-45.

- (1808), "Villemoes", Ny danske Tilskuer, No. 43 og 44, den 26. Mai 1808, København. Optrykt i US I, 753-755, hvorfra der her citeres.

— (1811), "Farvel til min Ven F. C. Sibbern" i PS I, 322-329, i revideret form under titlen "Til Sibbern" sst. 329-335.

- (1813), "Om Afguderie", Nyeste Skilderie af Kjøbenhavn Tirsdagen den 22. Juni 1813, København. Optrykt i US II, 694698 , hvorfra der her citeres.

- (1815), "Gunderslev Skov", Kvadlinger eller Smaakvad, København. Optrykt i PS I, 37-41, hvorfra der her citeres.

- (1815), "Til Cathrine Marie Bang min elskede Moder", Kvadlinger eller Smaakvad, København. Optrykt i US III, 64-68, hvorfra der her citeres.

— (1866), "Nornerne" i PS IX, 204-216.

- (1869), Haandbog i Verdenshistorien, 2. udgave, bind I-III, København.

Grundtvig, Svend (udg.) (1880-1930), N. F. S. Grundtvigs Poetiske Skrifter, bind 1-9, København.

\section{Værker af andre forfattere}

Koch, Hal (1944), Grundtvig, København.

Kofoed, Niels (1954), Grundtvig som selvbiograf, København.

Lehmann, Edv. (1929), Grundtvig, København.

Lundgreen-Nielsen, Flemming (1980), Det handlende ord: N. F. S. Grundtvigs digtning, litteraturkritik og poetik 1798-1819, I-II, København. 
Michelsen, William (1956), Den scelsomme forvandling $i$ N.F. S. Grundtvigs liv, København.

Prenter, Regin (1983), Den kirkelige anskuelse, Christiansfeld.

Rønning, F. (1907-13), N. F. S. Grundtvig, I-IV, København.

Scharling, C. I. (1947), Grundtvig og Romantiken, København.

Thodberg, Chr. (1986), "Grundtvigs skovoplevelse i 1811 og prædikenerne over Peters fiskedræt i tiden, der fulgte", GrundtvigStudier 1986, 11-55, København. Optrykt i Chr. Thodberg (1989), Syn og sang - Poesi og teologi hos Grundtvig, 242-95, København.

\section{Noter}

At Anja Stokholm i sin glimrende artikel "Om forholdet mellem skabelse og syndefald hos Grundtvig og Luther" (Grundtvig-Studier 2003, København, 88-121) påviser betydelige uoverensstemmelser mellem deres betragtninger over det naturlige menneskeliv (120), kan næppe anfægte den her fremførte opfattelse, idet de jo er enige om syndefaldets radikalitet (94-95), og idet Grundtvig netop betragter det positive ved det naturlige menneskeliv som et lån fra Gud (96-97) og som "Guds værk i os" (116). 